\title{
Manajemen Laba Terhadap Nilai Perusahaan Pada Pergantian CEO
}

\section{Dwi Cahyadi Tantra Wijaya ${ }^{1}$ \\ I G.A.N Budiasih ${ }^{2}$}

\author{
${ }^{1}$ Fakultas Ekonomi dan Bisnis Universitas Udayana (Unud), Bali, Indonesia \\ email: dwi.cahyadi0003@gmail.com/Telp: +6281999795454 \\ ${ }^{2}$ Fakultas Ekonomi dan Bisnis Universitas Udayana (Unud), Bali, Indonesia
}

\begin{abstract}
ABSTRAK
Tujuan penelitian ini adalah untuk mengetahui pengaruh manajemen laba pada nilai perusahaan dengan pola income increasing saat akhir jabatan CEO lama dan pola income decreasing saat awal jabatan CEO baru pada perusahaan yang terdaftar di Bursa Efek Indonesia (BEI). Penelitian ini dilakukan pada perusahaan yang terdaftar di BEI tahun 2010 - 2017. Sampel dalam penelitian ini 45 perusahaan pada pengamatan akhir jabatan CEO lama dan 54 perusahaan pada pengamatan awal jabatan CEO baru yang didapat dengan metode purposive sampling. Teknik analisis data yang digunakan adalah regresi linier sederhana. Hasil menunjukkan manajemen laba dengan pola income increasing saat akhir tahun jabatan CEO, dan manajemen laba dengan pola income decreasing saat awal jabatan CEO baru berpengaruh negatif pada nilai perusahaan.

Kata kunci: nilai perusahaan, manajemen laba, pergantian $\mathrm{CEO}$, income increasing, income decreasing.
\end{abstract}

\begin{abstract}
The purpose of this study was to determine the effect of earnings management on firm value with income increasing patterns at the end of old CEO position and income decreasing patterns at the beginning of new CEO position in companies that are listed on the Indonesia Stock Exchange (IDX). This research conducted on companies listed on the Stock Exchange in 2010 - 2017. Samples in this study were 45 companies in observation of the old CEO position and 54 companies in observation of the new CEO position obtained by purposive sampling method. The data analysis technique used is simple linear regression. The results show that earnings management with income increasing patterns at the end of the year of CEO's position, and earnings management with income decreasing patterns at the beginning of new CEO's position negatively affects firm value.

Keywords: firm value, earnings management, CEO turnover, income increasing, income decreasing.
\end{abstract}

\section{PENDAHULUAN}

Pada awalnya tujuan perusahaan berdiri adalah untuk mendapatkan keuntungan sebesar mungkin untuk mensejahterakan pemilik perusahaan, namun bagi perusahaan yang listing di bursa saham memiliki tujuan selain mendapatkan keuntungan yaitu untuk memaksimalkan nilai perusahaan yang tercermin dari harga sahamnya. Nilai perusahaan menggambarkan kondisi yang telah dicapai perusahaan sebagai wujud kepercayaan investor terhadap perusahaan selama 
beberapa periode (Astiti \& Damayanthi, 2018). Peningkatan nilai perusahaan mampu menggambarkan peningkatan kemakmuran pemegang saham ketika harga saham perusahaan meningkat (Lesmana \& Sukartha, 2017). Meningkatnya harga saham akan menunjukkan nilai perusahaan yang tinggi sehingga akan menarik perhatian investor untuk menginvestasikan dananya pada perusahaan tersebut.

Perusahaan yang listing di BEI diwajibkan untuk melakukan pelaporan laporan keuangan sesuai persyaratan Otoritas Jasa Keuangan (OJK). Pelaporan keuangan digunakan sebagai sumber informasi dalam pengambilan keputusan oleh para pengguna laporan keuangan seperti investor dan kreditur. Salah satu tolak ukur yang digunakan dalam penilaian kinerja perusahaan oleh pengguna laporan keuangan adalah laba (Dewi, 2013). Para investor seringkali lebih fokus terhadap informasi laba dalam laporan keuangan tanpa melihat bagaimana laba tersebut dihasilkan, dengan harapan perusahaan yang memiliki laba yang tinggi pada akhirnya akan memberikan tingkat return yang tinggi bagi investor (Erawan \& Ulupui, 2013). Informasi laba pada laporan keuangan merupakan hal yang paling sering menjadi sasaran manajemen dalam melakukan tindakan oportunis untuk memaksimalkan kepuasannya. Tindakan oportunis yang dilakukan manajemen adalah melalui pemilihan kebijakan akuntansi sesuai ketentuan yang ada untuk mengatur laba yang ingin di sajikan baik dengan cara pemilihan kebijakan untuk menaikkan maupun menurunkan laba sesuai keinginan manajemen yang disebut manajemen laba. Ung (2008) menyatakan salah satu insentif manajemen dalam melakukan manajemen laba adalah untuk mempengaruhi kinerja harga saham jangka pendek. 
Kasus seputar manajemen laba masih ditemukan baik di luar maupun dalam negeri. Pada tahun 2015 terdapat skandal akuntansi terbesar di Jepang dalam beberapa tahun terakhir. CEO dan Presiden Thosiba, Hisao Tanaka, mengundurkan diri setelah dinyatakan menggelembungkan keuntungan selama enam tahun terakhir (www.beritasatu.com, 2015). Sedangkan di Indonesia juga terdapat kasus dimana pada 13 Februari 2015 saham PT Inovisi Inovisi Infracom Tbk (INVS) dihentikan perdangannya di BEI. BEI menemukan sekitar delapan kesalahan dalam laporan keuangan pada kuartal III-2014. Menurut Kepala Riset NH Korindo, Reza Priyambada laporan keuangan terkesan dimanipulasi, dan ada kemungkinan ke arah membohongi investor (www.detikfinance.com, 2015). Pada akhirnya BEI menghapus pencatatan saham PT Inovisi Infracom Tbk (INVS) pada 23 Oktober 2017 (www.economy.okezone.com, 2017). Manajemen laba terjadi dipengaruhi oleh adanya konflik perbedaan kepentingan antara pemegang saham (principal) dengan manajemen (agent) selaku pengelola perusahaan yang timbul karena setiap pihak berusaha untuk mencapai atau mempertimbangkan tingkat kemakmuran yang dikehendakinya (Lestari \& Pamudji, 2013).

Terdapat beberapa motivasi manajemen melakukan manajemen laba salah satunya adalah pergantian Chief Excecutive Officer (CEO)(Scott, 2015, p. 448). CEO diberikan wewenang oleh pemilik perusahaan untuk mengatur jalannya aktivitas perusahaan, hal ini menyebabkan CEO memiliki informasi yang lebih mengenai perusahaan dibandingkan pemilik perusahaan. Sejalan dengan wewenang yang diberikan maka CEO harus bertanggung jawab untuk mampu memenuhi keinginan pemilik perusahaan yaitu meningkatkan kesejahteraan 
pemegang saham. Pihak principal memberikan bonus jika CEO mampu mencapai target laba tertentu dan CEO juga menghadapi resiko kehilangan pekerjaan jika tidak mampu memenuhi keinginan principal. Resiko kehilangan pekerjaan atas tidak mampunya menghasilkan kinerja perusahaan yang baik menyebabkan CEO melakukan manajemen laba yang meningkatkan labauntuk menutupi kinerja perusahaan yang buruk (Hazarika et al, 2012). Kalyta (2009) menemukan bahwa terdapat discretionary accrual yang tinggi pada tahun-tahun terakhir CEO menjabat ketika program pensiunan eksekutif berdasarkan kinerja.

Tabel 1.

Data Laba Bersih Saat Pergantian CEO (Dalam Jutaan Rupiah)

\begin{tabular}{lcccc}
\hline \multicolumn{1}{c}{ Nama Perusahaan } & $\mathbf{2 0 1 3}$ & $\mathbf{2 0 1 4}$ & $\mathbf{2 0 1 5}$ & $\mathbf{2 0 1 6}$ \\
\hline PT. Bukit Asam Tbk & 1.854 .281 & 1.863 .781 & 2.037 .111 & 2.024 .405 \\
PT. Cakra Mineral Tbk & 257 & -56.541 & 48.484 & -3.958 \\
PT. Timah (Persero) Tbk & 580.57 & 637.954 & 101.561 & 251.969 \\
PT. Intanwijaya Internasional Tbk & 11.028 & 16.961 & 9.989 & 165.54 \\
PT. Adhi Karya (Persero) Tbk & 409.861 & 326.656 & 465.025 & 315.108 \\
\hline Sumber: Data diolah, 2018 & & & &
\end{tabular}

Pada Tabel 1 disajikan contoh beberapa perusahaan yang terdaftar di BEI tahun 2010 sampai 2017 dengan laba bersih sekitar peristiwa pergantian CEO. Dari tabel tersebut peningkatan laba yang terjadi saat akhir jabatan CEO lama PT. Bukit Asam Tbk, PT. Cakra Mineral Tbk, PT. Adhi Karya (Persero) Tbk pada tahun 2015. PT. Timah (Persero) Tbk, PT. Intanwijaya Internasional Tbk pada tahun 2014. Kemudian penurunan laba yang terjadi saat awal jabatan CEO baru PT. Bukit Asam Tbk, PT. Cakra Mineral Tbk, PT. Adhi Karya (Persero) Tbk pada tahun 2016. PT. Timah (Persero) Tbk, PT. Intanwijaya Internasional Tbk pada tahun 2015 .

Dari perubahan laba yang terjadi ketika peristiwa pergantian CEO memunculkan kemungkinan bahwa manajemen melakukan manajemen laba yang 
cenderung menurunkan laba (income decreasing) ketika laba bersih turun atau rugi dan menaikkan laba (income increasing) ketika laba meningkat dari sebelumnya saat pergantian CEO. Eisenhardt (1989) menyatakan asumsi sifat manusia (mementingkan diri sendiri, memiliki keterbatasan rasionalitas, dan menghindari resiko). CEO yang akan habis masa kontraknya cenderung untuk menerapkan metode akuntansi yang menaikkan laba untuk memaksimumkan bonus terakhir yang akan diterima. CEO yang baru menjabat melakukan manajemen laba untuk melindungi diri mereka dalam mengantisipasi kejadiankejadian yang tidak terduga dan menghindari resiko kerugian di periode berikutnya dengan menurunkan laba atau melakukan big bath dengan melimpahkan kesalahan pada kepemimpinan CEO sebelumnya yang buruk.

DeAngelo’s (1986) dalam penelitiannya atas perebutan 86 kursi direksi perusahaan yang terdaftar di U.S dari 1970 sampai 1983 menyimpulkan direksi yang masih menjabat mencoba untuk meningkatkan pendapatan selama masa perebutan kursi untuk menunjukkan kinerja yang lebih baik agar mendapatkan posisi yang lebih baik dalam memperoleh suara pemegang saham. Pourciou (1993) menemukan bahwa direksi yang baru melakukan akrual yang menurunkan laba pada saat pergantian dan meningkatkan laba di tahun berikutnya. Wells (2002) menemukan bahwa CEO yang baru melakukan big bath dikarenakan CEO baru umumnya tidak terkait dengan keputusan masa sebelum CEO baru menjabat sehingga melakukan manajemen laba yang menurunkan laba.

Terdapat beberapa penelitian tentang manajemen laba dan nilai perusahaan yang telah dilakukan dimana penelitian menurut Ridwan dan Gunardi (2013), 
Susanto dan Christiawan (2016), Lesmana dan Sukartha (2017) menunjukkan manajemen laba berpengaruh positif pada nilai perusahaan. Penelitian menurut Lestari dan Pamudji (2013), Gill et al(2013), Febriani (2014) menunjukkan manajemen laba berpengaruh negatif pada nilai perusahan. Sedangkan penelitian menurut Darwis (2012), dan Surifah (2017) menunjukkan manajemen laba tidak berpengaruh pada nilai perusahaan. Penelitian ini merupakan replikasi riset terdahulu tentang pengaruh manajemen laba pada nilai perusahaan mengingat masih banyaknya penelitian-penelitian terdahulu yang memiliki hasil berbeda. Pengembangan penelitian ini dilakukan untuk mengetahui pengaruh manajemen laba pada nilai perusahaan saat akhir jabatan CEO lama dan awal jabatan CEO baru. Penggunaan peristiwa pergantian CEO menarik untuk digunakan dalam mengamati pengaruh manajemen laba pada nilai perusahaan mengingat pergantian CEO merupakan salah satu motivasi yang mendasari perilaku manajemen untuk melakukan manajemen laba.

Rumusan masalah dalam penelitian ini adalah apakah manajemen laba berpengaruh pada nilai perusahaan saat akhir jabatan CEO lama, danapakah manajemen laba berpengaruh pada nilai perusahaan saat awal jabatan CEO baru. Berdasarkan rumusan masalah yang ada maka yang menjadi tujuan di dalam penelitian ini adalah untuk mengetahui ada tidaknya pengaruh manajemen laba pada nilai perusahaan saat akhir jabatan CEO lama, dan untuk mengetahui ada tidaknya pengaruh manajemen laba pada nilai perusahaan saat awal jabatan CEO baru. Penelitian ini diharapkan mampu memberikan kontribusi dalam bidang ilmu akuntansi, khususnya mengenai nilai perusahaan, manajemen laba, serta teori 
sinyal dan keagenan. Serta dapat memberikan informasi kepada pengguna laporan keuangan agar dapat mengambil keputusan yang baik dan mampu menilai informasi laba yang disajikan oleh perusahaan.

Teori yang menjelaskan hubungan antara manajemen laba dan nilai perusahaan adalah teori sinyal. Menurut Brigham dan Houston (2011) sinyal adalah suatu tindakan yang manajemen perusahaan lakukan untuk memberi petunjuk bagi investor tentang bagaimana manajemen memandang prospek perusahaan. Sinyal dapat berupa informasi yang menyatakan bahwa perusahaan tersebut lebih baik daripada perusahaan lain (Susanto \& Christiawan, 2016). Dorongan perusahaan memberikan informasi kepada pihak eksternal dikarenakan adanya asimetri informasi dimana pihak eksternal memiliki jumlah informasi yang lebih sedikit tentang perusahaan dibandingkan manajemen selaku pengelola perusahaan. Kurangnya jumlah informasi yang dimiliki menyebabkan pihak eksternal melindungi diri mereka dengan memberikan harga yang rendah pada perusahaan. Perusahaan dapat mengurangi asimetri informasi ini dengan cara memberikan informasi perusahaan kepada pihak eksternal yang nantinya akan meningkatkan nilai perusahaan. Informasi yang diberikan oleh perusahaan dapat direspon sebagai sinyal baik (good news) dan sinyal buruk (bad news).

Teori keagenan menjelaskan konflik yang terjadi antara CEO dan investor. Teori keagenan menjelaskan hubungan keagenan adalah sebuah kontrak antara manajer selaku pengelola perusahaan (agent) dengan investor sebagai pemilik perusahaan (principal) (Jensen \& Meckling, 1976). Sukartha (2007) menyatakan bahwa kontrak yang efisien akan terjadi apabila (1) agen dan prinsipal memiliki 
informasi yang simetris artinya agen dan prinsipal memiliki informasi dengan kualitas dan kuantitas yang sama, dan (2) risiko yang dibebankan kepada agen terkait imbal jasa yang diterimanya adalah kecil artinya agen memiliki kepastian yang tinggi atas imbalan yang diterimanya. Kontrak yang efisien dalam praktiknya jarang terjadi dikarenakan prinsipal umumnya tidak berperan aktif dalam pengelolaan perusahaan dibandingkan agen. Keadaan ini menyebabkan terdapatnya asimetri informasi dalam hubungan prinsipal dan agen. Eisenhardt (1989) menyatakan bahwa terdapat tiga asumsi yang melandasi teori keagenan. Asumsi tersebut adalah (1) asumsi sifat manusia (mementingkan diri sendiri, memiliki keterbatasan rasionalitas, dan menghindari resiko), (2) asumsi keorganisasian (adanya konflik antara anggota dalam organisasi dan adanya asimetri informasi antara prinsipal dan agen), (3) asumsi informasi (informasi merupakan komoditi yang dapat diperjualbelikan). Dalam hubungan keagenan terdapat dua masalah keagenan yang ada yaitu asimetri informasi dan konflik kepentingan. Manajer selaku pengelola perusahaan memiliki informasi yang lebih dibandingkan investor, sehingga informasi yang dimiliki prinsipal tidak sama seperti agen yang mengakibatkan adanya asimetri informasi. Asimetri informasi antara manajer dan pemilik akan memberikan kesempatan kepada manajer untuk memperoleh keuntungan pribadi dengan manajemen laba (Schipper, 1989).

Nilai perusahaan pada dasarnya dapat diukur dari beberapa aspek salah satunya adalah harga saham perusahaan. Harga saham perusahaan mencerminkan bagaimana penilaian investor atas keseluruhan ekuitas yang dimiliki perusahaan (Astiti \& Damayanthi, 2018). Nilai perusahaan merupakan konsep penting bagi 
investor dalam menilai perusahaan secara keseluruhan yang dikaitkan dengan harga saham.

Menurut Scott (2015) manajemen laba adalah pemilihan kebijakan akuntansi tertentu oleh manajer untuk mencapai tujuan tertentu. Menurut Healy dan Wahlen (1998), manajemen laba terjadi ketika manajer menggunakan penilaian dalam laporan keuangan dan penyusunan transaksi untuk mengubah laporan keuangan yang berdampak pada kesalahanpahaman beberapa stakeholder dalam menilai kinerja ekonomi perusahaan maupun untuk mempengaruhi hasil kontrak yang bergantung pada angka akuntansi. Manajemen laba menyebabkan bias dalam laporan keuangan dikarenakan informasi yang dilaporkan tidak sesuai dengan yang ada sehingga mampu menyebabkan kesalahan dalam mengambil keputusan bagi pihak berkepentingan. Mostafa (2017) dalam penelitiannya menemukan bahwa perusahaan dengan kinerja yang rendah melakukan manajemen laba dengan meningkatkan laba yang dilaporkan untuk menutupi rendahnya kinerja perusahaan. Terdapat beberapa faktor yang memotivasi manajer melakukan manajemen laba salah satunya pergantian CEO (Scott, 2015, p. 448).

Motivasi manajemen laba yaitu pergantian CEO akan menjadi hal yang diperhatikan dalam penelitian ini. Chief Executife Officer (CEO) sebagai pimpinan manjerial dalam perusahaan diharapkan selalu meningkatkan kinerjanya dan kinerja perusahaan serta mampu mencapai tujuan yang diinginkan pemilik perusahaan. CEO di Indonesia lebih dikenal dengan istilah direktur utama, dimana presiden direktur merupakan penyebutan secara umum terhadap pimpinan suatu perusahaan dalam perseroan terbatas (Adiasih \& Kesuma, 2011). Jayanti dan 
Putra (2013) dalam penelitiannya menemukan praktik manajemen laba income increasing terjadi pada periode akhir masa jabatan CEO lama. Hal ini dapat disebabkan karena CEO yang akan berhenti dari perusahaan memiliki dorongan untuk memanipulasi laba guna memperoleh bonus yang lebih tinggi dan meningkatkan reputasinya. Praktik manajemen laba income decreasing terjadi pada periode awal masa jabatan CEO baru. Hal ini dapat disebabkan karena CEO baru pada tahun pertama jabatannya tidak bertanggungjawab atas kinerja buruk CEO sebelumnya. Laba buruk yang dilaporkan pada tahun pertama masa jabatan CEO baru dapat secara eksplisit dikatakan adalah akibat dari buruknya kinerja CEO sebelumnya. Vancil (1987) menyatakan beberapa hal yang harus dihadapi dalam tahun awal jabatannya (1) mengatur ekspektasi para pemangku kepentingan, (2) mengambil kepemimpinan atas strategi perusahaan dalam masa jabatannya, (3) membangun kepercayaan kepada semua pihak dengan mencapai target kinerja dalam tahun pertama atau kedua jabatannya.

Teori keagenan menjelaskan hubungan kontrak prinsipal dan agen, dimana dalam menjalankan perusahaan prinsipal mendelegasikan wewenang kepada agen untuk menjalankan perusahaan demi kepentingan prinsipal. Manajer yang aktif dalam operasional perusahaan memiliki informasi yang lebih banyak dibandingkan prinsipal yang pasif dalam operasional perusahaan sehingga menimbulkan adanya asimetri informasi. Adanya asimetri informasi memberikan peluang manajer dalam melakukan manajemen laba. Perusahaan yang melakukan manajemen laba yang besar (kecil) cenderung mengalami agency cost yang rendah (tinggi) (Jiraporn et al, 2008). Manajemen laba yang dilakukan CEO 
terjadi karena kecendrungan laba yang dijadikan sebagai indikator penilaian prestasi CEO dalam menjalankan perusahaan (Dewi \& Rasmini, 2018). Jayanti dan Putra (2013), Dewi dan Rasmini (2018) menyatakan terdapatnya paktik manajemen laba dengan menaikkan laba (income increasing) pada akhir jabatan CEO lama. Hal ini bisa terjadi karena CEO yang akan mengakhiri masa jabatannya di suatu perusahaan memiliki dorongan untuk memanipulasi laba guna memperoleh bonus yang lebih tinggi di masa akhir jabatannya. Manajemen laba dalam jangka pendek memiliki pengaruh positif terhadap nilai perusahaan (Subanidjaet al, 2016)

Ketika manajemen laba yang dilakukan dengan menaikkan laba atau income increasing, maka akan terjadi kenaikan kemakmuran yang diterima pemegang saham. Peningkatan laba dianggap sebagai sinyal baik bagi investor, kreditur, dan pihak berkepentingan lainnya. Sinyal baik ini memberikan sentiment positif bagi investor sehingga memberikan harga yang tinggi bagi perusahaan yang berakibat meningkatnya nilai perusahaan. Bedasarkan uraian tersebut maka diambil hipotesis sebagai berikut:

$\mathrm{H}_{1}$ : Manajemen laba dengan pola income increasing saat akhir jabatan CEO lama berpengaruh positif pada nilai perusahaan.

Manajer sebagai pihak yang diberi wewenang dalam menjalankan perusahaan mempunyai tanggung jawab melakukan pengungkapan informasi akuntansi berupa laporan keuangan untuk memberitahukan kondisi perusahaan kepada pihak yang berkepentingan (Hardiningsih \& Oktaviani, 2012). Saat melakukan pengungkapan informasi keuangan manajer sering memanfaatkan kesempatan ini untuk melakukan manajemen laba. Untuk memanajemen 
ekspektasi para pemangku kepentingan atas kinerja perusahaan, CEO baru cenderung melimpahkan kinerja buruk periode sebelumnya kepada CEO lama karena CEO baru tidak bertanggung jawab atas kinerja periode sebelumnya. Penelitian Bengtsson dan Nilsson (2007), Wijaya dan Ardiana (2014) menemukan pada periode awal masa jabatannya, CEO baru terbukti melakukan praktik manajemen laba yang menurunkan laba (income decreasing) untuk memperbesar kemungkinan memperoleh laba yang lebih tinggi pada periode berikutnya.

Ketika manajemen laba yang dilakukan dengan menurunkan laba atau income decreasing, maka akan terjadi penurunan kemakmuran yang diterima pemegang saham. Penurunan laba dianggap sebagai sinyal buruk bagi investor, kreditur, dan pihak berkepentingan lainnya. Sinyal buruk ini memberikan sentiment negatif bagi investor sehingga memberikan harga yang rendah bagi perusahaan yang berakibat menurunnya nilai perusahaan. Bedasarkan uraian tersebut maka diambil hipotesis sebagai berikut:

$\mathrm{H}_{2}$ : Manajemen laba dengan pola income decreasing saat awal jabatan CEO baru berpengaruh negatif pada nilai perusahaan.

\section{METODE PENELITIAN}

Penelitian ini dilakukan dengan pendekatan kuantitatif dengan tingkat eksplanasi asosiatif. Penelitian ini dilakukan pada seluruh perusahaan yang terdaftar di Bursa Efek Indonesia (BEI) pada tahun 2010-2017 yang dapat diakses di situs www.idx.co.id. Data pergantian CEO periode 2010-2017 diperoleh dengan mengakses Indonesia Capital Market Directory (ICMD) dan laporan tahunan maupun keuangan perusahaan yang bisa diakses di situs website perusahaan bersangkutan dan www.idx.co.id. Alasan dilakukannya penelitian ini pada seluruh 
sektor yang terdaftar di BEI karena ditemukan penelitian sebelumnya yang melakukan penelitian mebagi ke sektor-sektor tertentu di BEI. Sehingga digunakan semua perusahaan yang terdaftar di BEI untuk mendapatkan hasil yang lebih tergeneralisasi. Objek dari penelitian ini adalah nilai perusahaan yang terdaftar di BEI tahun 2010-2017 yang dipengaruhi oleh manajemen laba. Variabel terikat untuk penelitian ini adalah nilai perusahaan dan variabel bebas dalam penelitian ini adalah manajemen laba.

Variabel nilai perusahaan diproksikan dengan Tobin's Q. Perhitungan Tobin's $\mathrm{Q}$ dalam penelitian ini menggunakan rumus yang dikembangkan oleh Chung dan Pruitt (1994). Rumus Tobin's Q dalam penelitian ini adalah sebagai berikut:

$$
\text { Tobin's Q= } \frac{\text { MVE }+ \text { DEBT }}{\text { TA }}
$$

Keterangan:

$\begin{array}{ll}\text { Tobin's Q } & =\text { Nilai Perusahaan } \\ \text { MVE } & \text { Nilai Pasar Ekuitas (closing price saham X jumlah } \\ & \quad \text { saham beredar) } \\ \text { DEBT } & \text { Total Utang Perusahaan } \\ \text { TA } & =\text { Total Aktiva }\end{array}$

Variabel manajemen laba diproksikan dengan akrual diskresioner (DA), yang diukur dengan menggunakan model Jones modifikasian (Modified Jones Model) (Dechow et al, 1995). Saiful (2004) menyatakan bahwa Modified Jones Model lebih mudah untuk digunakan untuk berbagai jenis perusahaan (perbedaan sektor). Akrual diskresioner dapat dihitung dengan rumus berikut:

Mencari nilai total accrual:

$$
\mathrm{TACi}_{\mathrm{t}}=\mathrm{Ni}_{\mathrm{t}}-\mathrm{CFOi}_{\mathrm{t}}
$$


Mencari nilai koefisien regresi:

$$
\mathrm{TACi}_{\mathrm{t}} / \mathrm{Ai}_{\mathrm{t}-1}=\beta 1\left(1 / \mathrm{Ai}_{\mathrm{t}-1}\right)+\beta 2\left(\Delta \mathrm{Rev}_{\mathrm{t}} / \mathrm{Ai}_{\mathrm{t}-1}-\Delta \mathrm{Rec}_{\mathrm{t}} / \mathrm{Ai}_{\mathrm{t}-1}\right)+\beta 3\left(\mathrm{PPEt} / \mathrm{Ai}_{\mathrm{t}-1}\right) \ldots \text { (3) }
$$

Berdasarkan koefisen regresi dari persamaan sebelumnya maka nilai non discretionary accruals dapat dihitung dengan persamaan:

$$
N_{D A i}=\beta 1\left(1 / A_{t}-1\right)+\beta 2\left(\Delta \operatorname{Rev}_{t} / A_{t}-1-\Delta \operatorname{Rec}_{t} / A i_{t-1}\right)+\beta 3\left(P P E t / A i_{t-1}\right) \ldots \ldots(4)
$$

Sehingga Discretionary Accrual (DA) dapat dihitung dengan rumus:

$$
D A i_{t}=T A C i_{t} / A i_{t-1}-N D A i_{t}
$$

Keterangan:

$\mathrm{DAi}_{\mathrm{t}}=$ Discretionary accruals perusahaan i pada periode $\mathrm{ke} \mathrm{t}$

NDAi $_{\mathrm{t}}=$ Non discretionary accrual perusahaan i pada periode $\mathrm{ke} \mathrm{t}$

$\mathrm{TACi}_{\mathrm{t}}=$ Total accrual perusahaan i pada periode ke $\mathrm{t}$

$\mathrm{Ni}_{\mathrm{t}} \quad=$ Laba bersih perusahaan $\mathrm{i}$ pada periode ke $\mathrm{t}$

$\mathrm{CFOi}_{\mathrm{t}}=$ Aliran kas dari aktivitas operasi perusahaan i pada periode ke $\mathrm{t}$

$\mathrm{Ai}_{\mathrm{t}-1}=$ Total aktiva perusahaan $\mathrm{i}$ pada periode ke $\mathrm{t}-1$

$\Delta \operatorname{Rev}_{\mathrm{t}}=$ Perubahan pendapatan perusahaan i pada periode ke $\mathrm{t}$

$\mathrm{PPE}_{\mathrm{t}} \quad=$ Aktiva tetap perusahaan i pada periode ke $\mathrm{t}$

$\Delta \operatorname{Rec}_{\mathrm{t}}=$ Perubahan piutang perusahaan i pada periode ke $\mathrm{t}$

Data yang digunakan dalam penelitian ini adalah data kuantitatif. Dalam hal ini data kuantitatif yang diperlukan adalah angka-angka dalam laporan keuangan tahunan pada perusahaan yang terdaftar di BEI. Sumber data yang digunakan dalam penelitian ini adalah data sekunder. Populasi yang terdapat dalam penelitian ini adalah seluruh perusahaan yang terdaftar di BEI pada tahun 2010-2017. Sampel ditentukan dengan kriteria purposive sampling sebagai berikut: (1) perusahaan terdaftar di Bursa Efek Indonesia secara berturut-turut pada tahun 2010-2017, (2) perusahaan yang terdaftar mengalami pergantian CEO, (3) CEO minimal sudah menempuh 2 tahun masa jabatan, (4) perusahaan menggunakan satuan rupiah (Rp) pada laporan keuangan yang diterbitkan, (5) 
perusahaan menerbitkan laporan keuangan dan laporan tahunan lengkap untuk tahun2010-2017 per 31 Desember (6) perusahaan memiliki Discretionary Accrual (DA) positif saat CEO lama menjabat dan negatif saat CEO baru menjabat.Teknik purposive sampling adalah teknik untuk menentukan sampel penelitian dengan beberapa pertimbangan tertentu yang bertujuan agar data yang diperoleh nantinya bisa representatif (Sugiyono, 2016, p. 96). Metode pengumpulan data dilakukan dengan metode obervasi non partisipan. Teknik analisis data yang dilakukan dalam penelitian ini adalah statistik deskriptif, uji normalitas menggunakan uji Kolmogorov-Smirnov, uji autokorelasi menggunakan uji Durbin-Watson, uji heterokedastisitas menggunakan uji glejser, regresi linier sederhana dengan menggunakan program Statistical Package for Social Science (SPSS) 20. Penerimaan dan penolakan hipotesis didasarkan pada significant p-value.Jika $p$ value $>$ 0,05 maka hipotesis diterima, dan jika $p$-value $\leq 0,05$ maka hipotesis ditolak (Ghozali, 2016, p. 66). Persamaan regresi yang digunakan diformulasikan sebagai berikut:

$$
\begin{aligned}
& \mathrm{Y}_{1}=\alpha+\beta . \mathrm{X}_{1}+\varepsilon . \\
& \mathrm{Y}_{2}=\alpha+\beta . \mathrm{X}_{2}+\varepsilon .
\end{aligned}
$$

Keterangan:

$\mathrm{Y}_{1}$ = Nilai perusahaan saat akhir jabatan CEO lama

$\mathrm{Y}_{2}=$ Nilai perusahaan saat awal jabatan CEO baru

$\alpha \quad=$ Konstanta

$\beta=$ Koefisien regresi

$\mathrm{X}_{1}$ = Manajemen laba saat akhir jabatan CEO lama

$\mathrm{X}_{2}$ = Manajemen laba saat awal jabatan CEO baru

$\varepsilon \quad=$ errorterm 


\section{HASIL DAN PEMBAHASAN}

BEI sebagai lembaga pasar modal Indonesia menyediakan informasi mengenai aktivitas bursa dan data terkait perusahaan-perusahaan yang telah go public di Indonesia. Berdasarkan purposive sampling didapatkan pengamatan perusahaan yang melakukan manajemen laba dengan pola income increasing saat akhir jabatan CEO lama sebanyak 56 pengamatan dan manajemen laba dengan pola income decreasing saat awal jabatan CEO baru didapat sebanyak 59 pengamatan. Untuk mendapatkan model yang lolos uji asumsi klasik, dilakukan outlier data sehingga menyebabkan pengamatan berkurang menjadi 45 pengamatan untuk data pada kelompok income increasing saat akhir jabatan CEO lama dan 54 pengamatan untuk data pada kelompok income decreasing saat awal jabatan CEO baru.

Tabel 2.

Hasil Statistik Deskriptif Variabel Penelitian

\begin{tabular}{lcrrrr}
\hline & N & Minimum & Maximum & \multicolumn{1}{c}{ Mean } & \multicolumn{1}{c}{$\begin{array}{c}\text { Std. } \\
\text { Deviation }\end{array}$} \\
\hline ML CEO Lama & 45 & 0,00023 & 0,32698 & 0,670469 & 0,0619512 \\
Q CEO Lama & 45 & 0,25589 & 2,39275 & 1,124814 & 0,5059669 \\
ML CEO Baru & 54 & $-5,51065$ & $-0,00313$ & $-0,223322$ & 0,7471916 \\
Q CEO Baru & 54 & 0,33281 & 11,13693 & 1,447533 & 1,4768946 \\
\hline Sumber: Data diolah, 2018 & & & & &
\end{tabular}

Statistik deskripitif menyampaikan informasi mengenai karakteristik variabel penelitian yang terdiri dari jumlah pengamatan, nilai minimum, nilai maksimum, nilai rata-rata (mean) dan standar deviasi. Hasil statistik deskriptif dapat dilihat pada Tabel 2.ML CEO Lama merupakanmanajemen laba dengan pola income increasing saat akhir tahun jabatan CEO lama (X1). Berdasarkan Tabel 2, nilai rata-rata variabel ML CEO Lamaadalah 0,670 dengan standar deviasi sebesar 0,062 . Nilai minimum adalah 0,00023 nilai maksimum sebesar 
0,327. Q CEO Lama merupakan nilai perusahaan saat akhir tahun jabatan CEO lama (Y1). Nilai rata-rata Q CEO Lama adalah 1,12 dengan standar deviasi sebesar 0,50. Nilai minimum adalah 0,25 sedangkan nilai maksimum sebesar 2,39 .

ML CEO Baru merupakan manajemen laba dengan pola income decreasing saat awal tahun jabatan CEO baru (X2). Berdasarkan Tabel 2, nilai rata-ML CEO Baru adalah -0,223 dengan standar deviasi sebesar 0,747. Nilai minimum adalah $-5,510$ sedangkan nilai maksimum sebesar -0,003.Q CEO Baru perusahaan merupakan nilai perusahaan saat awal jabatan CEO baru (Y2). Nilai rata-rata Q CEO Baru adalah 1,45 dengan standar deviasi sebesar 1.48. Nilai minimum adalah 0,33 sedangkan untuk nilai maksimum sebesar 11,14 .

Tabel 3.

Hasil Uji Normalitas

\begin{tabular}{cc}
\hline Akhir Tahun Jabatan CEO Lama & Unstandardized Residual \\
\hline N & 45 \\
Kolmogorov-Smirnov $Z$ & 1,036 \\
Asymp. Sig. (2-tailed) & 0,233 \\
\hline Awal Tahun Jabatan CEO Baru & Unstandardized Residual \\
\hline Nolmogorov-Smirnov $Z$ & 54 \\
Asymp. Sig. (2-tailed) & 1,237 \\
\hline
\end{tabular}

Sumber: Data diolah, 2018

Untuk menguji normalitas residual, digunakan uji Kolmogorov-Smirnov (K-S) dengan melihat nilai Asymp. Sig. (2-tailed). Jika tingkat signifikansinya > 0,05 maka data residual berdistribusi normal. Berdasarkan Tabel 3 dapat dilihat nilai Asymp. Sig. (2-tailed) untuk kelompok data akhir tahun jabatan CEO lama sebesar 0,233 dan kelompok data awal tahun jabatan CEO baru memiliki nilai Asymp. Sig. (2-tailed) sebesar 0,094. Hasil tersebut lebih besar dari nilai alpha 0,05 sehingga dapat dikatakan data residual terdistribusi normal. 
Tabel 4.

Hasil Uji Heteroskedastisitas

\begin{tabular}{ccccc}
\hline No & Persamaan & Variabel Bebas & Sig. & Keterangan \\
\hline 1 & $\mathrm{Y}_{1}=\alpha+\beta_{1} \mathrm{X}_{1}+\varepsilon$ & ML CEO Lama & 0,385 & Bebas heteros \\
2 & $\mathrm{Y}_{2}=\alpha+\beta_{2} \mathrm{X}_{2}+\varepsilon$ & ML CEO Baru & 0,869 & Bebas heteros
\end{tabular}

Sumber: Data diolah, 2018

Berdasarkan Tabel 4 dapat dilihat bahwa nilai signifikansi dari variabel manajemen laba saat akhir tahun jabatan CEO lama dan awal tahun jabatan CEO baru masing-masing sebesar 0,385 dan 0,869 . Nilai tersebut lebih besar dari 0,05 yang berarti tidak terdapat pengaruh antara variabel bebas terhadap absolute residual. Dapat disimpulkan model yang dibuat tidak mengandung gejala heteroskedastisitas.

Tabel 5.

Hasil Uji Autokorelasi

\begin{tabular}{cccccc}
\hline No & Persamaan & dl & du & DW & Simpulan \\
\hline 1 & $\mathrm{Y}_{1}=\alpha+\beta_{1} \mathrm{X}_{1}+\varepsilon$ & 1,475 & 1,566 & 2,132 & Bebas autokorelasi \\
2 & $\mathrm{Y}_{2}=\alpha+\beta_{2} \mathrm{X}_{2}+\varepsilon$ & 1,523 & 1,598 & 2,086 & Bebas autokorelasi \\
\hline Sumber: Data diolah, 2018 & & & &
\end{tabular}

Berdasarkan Tabel 5 dapat dilihat pada persamaan regresi pertama memiliki nilai Durbin-Watson sebesar 2,132. Untuk tingkat signifikansi 5\%, nilai $\mathrm{dl}=1,475 \mathrm{dan} \mathrm{du}=1,566$. Hasil uji autokorelasi persamaan regresi pertama dengan kriteria $\mathrm{du}<\mathrm{DW}<4$-du adalah $1,566<2,132<2,434$. Persamaan regresi kedua memiliki nilai Durbin-Watson sebesar 2,086. Untuk tingkat signifikansi 5\% nilai $\mathrm{dl}=1,523$ dan $\mathrm{du}=1,598$. Hasil uji autokorelasi persamaan regresi kedua dengan kriteria $\mathrm{du}<\mathrm{DW}<4$-du adalah $1,598<2,086<2,402$. Dapat disimpulkan bahwa kedua model regresi yang dibuat tidak mengandung gejala autokorelasi. 
Tabel 6.

Hasil Uji Regresi Linier Sederhana Pertama

\begin{tabular}{lcccc}
\hline \multicolumn{1}{c}{ Variabel } & Unstandardized Beta & Std. Error & t hitung & Sig. \\
\hline (Constant) & 1,296 & 0,107 & 12,057 & 0,000 \\
ML CEO Lama & $-2,549$ & 1,183 & $-2,154$ & 0,037 \\
\hline Adjusted R Square & 0,076 & & & \\
F Statistik & 4,639 & & & \\
Signifikansi Uji F & 0,037 & & & \\
\hline
\end{tabular}

Sumber: Data diolah, 2018

Berdasarkan Tabel 6 maka persamaan regresi yang pertama pada penelitian ini adalah $\mathrm{Y}_{1}=1,296-2,549 \mathrm{X}_{1}+\varepsilon$

Nilai konstanta sebesar 1,296 berarti ketika variabel bebas sama dengan nol, maka nilai perusahaan yang melakukan manajemen laba dengan pola income increasing saat akhir jabatan CEO lama akan meningkat sebesar 1,296.Nilai koefisien regresi variabel manajemen laba sebesar $-2,549$ berarti ketika variabel manajemen laba dengan pola income increasing saat akhir jabatan CEO lama meningkat satu satuan, maka nilai perusahaan akan menurun sebesar 2,549. Besarnya pengaruh variabel bebas terhadap variabel terikat pada persamaan regresi pertama tersebut ditunjukkan oleh nilai Adjusted $R$ Square sebesar 0,076, yang mempunyai arti bahwa sebesar 7,6\% variasi nilai perusahaan saat akhir tahun jabatan CEO lama dipengaruhi oleh variasi manajemen laba saat akhir tahun jabatan CEO lama, sedangkan sisanya sebesar 92,4\% dijelaskan oleh faktor lain yang tidak dimasukkan ke dalam model.

Berdasarkan hasil analisis pengaruh manajemen laba pada nilai perusahaan saat akhir jabatan CEO lama pada Tabel 6 diperoleh nilai signifikansi sebesar 0,037 dengan nilai koefisien beta -2,549. Nilai signifikansi $0,037<0,05$ mengindikasikan variabel manajemen laba dengan pola income increasing saat 
akhir jabatan CEO lama berpengaruh signifikan pada nilai perusahaan. Nilai koefisien beta negatif menandakan manajemen laba dengan pola income increasing saat akhir jabatan CEO lama memiliki pengaruh negatif pada nilai perusahaan sehingga hipotesis $\mathrm{H}_{1}$ ditolak. Hasil penelitian ini tidak sejalan dengan hasil yang didapatkan oleh Ridwan dan Gunardi (2013), Susanto dan Christiawan (2016), Lesmana dan Sukartha (2017) yang mendapatkan hasil manajemen laba berpengaruh positif terhadap nilai perusahaan.

Namun penelitian ini memiliki hasil yang sejalan dengan Gill et al (2013) dalam penelitiannya menemukan bahwa semakin tinggi aktifitas manajemen laba, semakin besar dampak negatif terhadap nilai perusahaan. Manajer cenderung melakukan manajemen laba dengan memindahkan keuntungan di periode yang akan datang ke periode saat ini untuk mendapatkan keuntungan dari pelaporan kinerja yang baik dengan biaya di periode yang akan datang sehingga akan berdampak di masa datang. Herawaty (2008) dalam penelitiannya menemukan manajemen laba berpengaruh negatif terhadap nilai perusahaan, dimana manajemen laba yang dilakukan perusahaan bukan untuk strategi meningkatkan nilai perusahaan. Siallagan (2009) dalam penelitian menemukan semakin kecil discretionary accrual (discretionary accrual yang rendah mengindikasikan kualitas laba yang tinggi) maka nilai perusahaan semakin tinggi.

Hasil penelitian ini sesuai dengan teori sinyal, dimana tindakan manajemen dalam melakukan manajemen laba dengan pola income increasing saat akhir jabatan CEO lama memberikan sinyal yang berpengaruh terhadap nilai perusahaan. Sinyal ini tidak direaksi investor sebagai good news melainkan bad 
news dikarenakan peningkatan laba yang terjadi dengan manajemen laba melalui discretionary accrual menyebabkan kualitas laba yang dilaporkan menjadi rendah sehingga direspon investor dengan menilai perusahaan dengan harga saham rendah. Adjusted $R$ Square sebesar 0,076 yang mempunyai arti bahwa sebesar 7,6\% variasi nilai perusahaan saat akhir tahun jabatan CEO lama dipengaruhi oleh variasi manajemen laba saat akhir tahun jabatan CEO lama, sedangkan sisanya sebesar 92,4\% dijelaskan oleh faktor lain yang tidak dimasukkan ke dalam model. Pengaruh manajemen laba dengan pola income increasing direspon negatif oleh investor bisa dipengaruhi oleh faktor eksternal. Sampel yang digunakan dalam uji statistik sebagian besar didapat pada periode tahun 2013 dan 2015 yang termasuk tahun yang sulit bagi perekonomian Indonesia. Pertumbuhan ekonomi Indonesia tahun 2013 sampai 2015 terus mengalami penurunan dimana tahun 2013 sebesar 5,78\%, 2014 sebesar 5,02\%, dan 2015 sebesar 4,79\%. Pada tahun 2013 Bank Sentral Amerika, Federal Reserve (The Fed) ikut mempengaruhi perekonomian negara berkembang termasuk Indonesia, melalui pengurangan stimulus moneter (Quantitative Easing). Kebijakan ini mendorong dana yang ditanamkan di negaranegara berkembang keluar, pindah ke portofolio berdenominasi dolar. Pada tahun 2014 kondisi ekonomi Indonesia dilanda gejolak politik Pemilu Presiden dan Pemilu Legislatif menyebabkan penundaan pada belanja pemerintah dan proyek infrastruktur. Pada tahun 2015 laju pertumbuhan ekonomi Tiongkok yang masih menunjukkan pelemahan sebagai salah satu pengguna komoditas sumber daya alam terbesar di dunia memberikan dampak negatif pada harga komoditas global dimana Tiongkok melakukan devaluasi mata uang Yuan untuk mengurangi impor 
dan meningkatkan ekspor. Kemudian terus melemahnya nilai tukar rupiah terhadap dolar Amerika Serikat serta ketidakpastian suku bunga The Fed menyebabkan kecendrungan masyarakat untuk berpindah ke insturmen investasi lain selain saham atau investor cenderung merespon dengan cara menunggu kondisi yang lebih stabil sehingga menyebabkan investor mengurungkan diri untuk membeli saham perusahaan walaupun memiliki kinerja laba yang baik.

Tabel 7.

\section{Hasil Uji Regresi Linier Sederhana Kedua}

\begin{tabular}{lcccc}
\hline \multicolumn{1}{c}{ Variabel } & $\begin{array}{c}\text { Unstandardized } \\
\text { Beta }\end{array}$ & Std. Error & t hitung & Sig. \\
\hline (Constant) & 1,054 & 0,096 & 11,012 & 0,000 \\
ML CEO Baru & $-1,764$ & 0,124 & $-14,252$ & 0,000 \\
Adjusted $R$ Square & 0,792 & & & \\
F Statistik & 203,114 & & & \\
Signifikansi Uji F & 0,000 & & & \\
\hline Sumber: Data diolah, 2018 & & &
\end{tabular}

Sumber: Data diolah, 2018

Berdasarkan Tabel 7 maka persamaan regresi yang kedua pada penelitian ini adalah $Y_{2}=1,054-1,764 \mathrm{X}_{2}+\varepsilon$

Nilai konstanta sebesar 1,054 berarti ketika variabel bebas sama dengan nol, maka nilai perusahaan yang melakukan manajemen laba dengan pola income decreasing saat awal jabatan CEO baru meningkat sebesar 1,054. Nilai koefisien regresi variabel manajemen laba sebesar -1,764 berarti ketika variabel manajemen laba dengan pola income decreasing saat awal jabatan CEO baru meningkat satu satuan, maka nilai perusahaan akan menurun sebesar 1,764. Adjusted $R$ Square sebesar 0,792 mempunyai arti bahwa sebesar 79,2\% variasi nilai perusahaan saat awal tahun jabatan CEO baru dipengaruhi oleh variasi manajemen laba saat awal tahun jabatan CEO baru, sedangkan sisanya sebesar $20.8 \%$ djelaskan oleh faktor lain yang tidak dimasukkan ke dalam model. 
Berdasarkan hasil analisis pengaruh manajemen laba pada nilai perusahaan saat awal jabatan CEO baru pada Tabel 7diperoleh nilai signifikansi sebesar 0,000 dengan nilai koefisien beta -1,764. Nilai Signifikansi $0,000<0,05$ mengindikasikan variabel manajemen laba dengan pola income decreasing saat awal jabatan CEO baru berpengaruh signifikan pada nilai perusahaan. Nilai koefisien beta positif menandakan manajemen laba dengan pola income decreasing saat awal jabatan CEO baru memiliki pengaruh negatif pada nilai perusahaan sehingga hipotesis $\mathrm{H}_{2}$ diterima. Hasil penelitian ini sejalan dengan hasil yang didapatkan oleh Lestari dan Pamudji (2013), Gill et al(2013), Febriani (2014), Lesmana dan Sukartha (2017) yang mendapatkan hasil manajemen laba berpengaruh negatif pada nilai perusahaan. Lesmana dan Sukartha (2017) menyatakan informasi penurunan laba mengandung perilaku oportunistik yang dapat merugikan pemegang saham, sehingga investor merespon informasi tersebut sebagai bad news yang menyebabkan menurunnya harga saham perusahaan yang berdampak pada menurunnya nilai perusahaan. Hal tersebut juga didukung oleh penelitian Lestari dan Pamudji (2013) yang menyatakan bahwa perusahaan yang melakukan manajemen laba yang tinggi akan dapat membuat nilai perusahaan menjadi rendah. Hasil penelitian ini sesuai dengan teori sinyal, dimana tindakan manajemen dalam melakukan manajemen laba dengan pola income decreasing saat awal jabatan CEO baru memberikan sinyal yang berpengaruh terhadap nilai perusahaan. Sinyal ini dianggap sebagai bad news dikarenakan manajemen laba yang dilakukan saat awal jabatan CEO baru dengan pola income decreasing menyebabkan penurunan laba yang dianggap sebagai sinyal buruk bagi pasar. 
Praktik manajemen laba yang mengandung perilaku oportunistik dapat menurunkan kepercayaan masyarakan kepada perusahaan sehingga berdampak pada menurunnya nilai perusahaan.

\section{SIMPULAN}

Manajemen laba dengan pola income increasing saat akhir jabatan CEO lama berpengaruh negatif dan signifikan pada nilai perusahaan. Peningkatan laba direspon investor sebagai sinyal buruk dikarenakan semakin besarnya manajemen laba dilakukan melalui discretionary accrual menyebabkan kualitas laba yang rendah sehingga pasar menilai perusahaan dengan harga saham yang rendah. Adjusted $R$ Square sebesar 7,6\% menjelaskan variasi nilai perusahaan saat akhir tahun jabatan CEO lama dipengaruhi oleh variasi manajemen laba saat akhir tahun jabatan CEO lama, sedangkan sisanya sebesar 92,4\% dijelaskan oleh faktor lain yang tidak dimasukkan ke dalam model. Dalam penelitian ini diduga disebabkan oleh faktor eksternal seperti pengaruh pertumbuhan ekonomi Indonesia yang sedang turun, nilai mata uang rupiah yang rendah atas dolar Amerika Serikat, serta ketidakpastian suku bunga The Fed yang membuat investor bersikap menunggu kondisi lebih stabil. Manajemen laba dengan pola income decreasing saat awal jabatan CEO baru berpengaruh negatif dan signifikan pada nilai perusahaan. Penurunan laba dianggap memberikan sinyal yang buruk sehingga memberi pengaruh penurunan harga saham, selain itu tindakan manajemen laba saat akhir jabatan CEO baru dengan pola income decreasing saat awal jabatannya dianggap mengandung perilaku oportunistik dapat menurunkan 
kepercayaan pasar terhadap perusahaan sehingga investor menilai perusahaan dengan harga saham yang rendah.

Berdasarkan hasil penelitian sebelumnya dan simpulan yang telah diuraikan, saran yang dapat diberikan adalah pergantian CEO dalam penelitian ini tidak memisahkan antar pergantian rutin maupun non rutin, CEO dari luar atau dalam perusahaan, sehingga diharapkan peneliti selanjutnya dapat memisahkan tipe pergantian CEO sesuai fokus masalah yang ingin diteliti. Bagi perusahaan agar dapat meminimalisir tindakan-tindakan yang dapat merugikan perusahaan terutama saat pergantian CEO melalui kontrak yang memenuhi kepentingan semua pihak untuk meminimalisir konflik kepentingan. Bagi investor atau pihak berkepentingan diharapkan dapat menganalisis lebih baik atas laporan keuangan yang dilaporkan saat peristiwa pergantian CEO agar dapat mengambil keputusan yang tepat.

\section{REFRENSI}

Adiasih, P., \& Kesuma, I. W. (2011). Manajemen Laba Pada Saat Pergantian CEO ( Dirut ) Di Indonesia. Jurnal Akuntansi Dan Keuangan, 13(2), 67-79.

Astiti, N. P. S., \& Damayanthi, I. G. A. E. (2018). Pengaruh Manajemen Laba pada Nilai Perusahaan Sesudah Pergantian Chief Executive Officer (CEO). EJurnal Akuntansi Universitas Udayana, 23(1), 185-210.

Bengtsson, K., \& Nilsson, M. (2007). Earnings Management and Ceo TurnoversA Study Of Swedish Corporations.Thesis, Stockholm School of Economics.

Brigham, E. F., \& Houston, J. F. (2011). Dasar-dasar Manajemen Keuangan (11th ed.). Jakarta: Salemba Empat.

Chung, K. H., \& Pruitt, S. W. (1994). A Simple Approximation of Tobin's q. Financial Management, 23(3), 70-74. 
Darwis, H. (2012). Manajemen Laba Terhadap Nilai Perusahaan Dengan Corporate Governance Sebagai Pemoderasi. Jurnal Keuangan Dan Perbankan, 16(1), 45-55.

DeAngelo, \& Elizabeth, L. (1986). Managerial Competition, Information Costs, And Corporate Governance: The Use Of Accounting Performance Measures In Proxy Contests. Journal of Accounting and Economics, 10(1), 3-36.

Dechow, P. M., Sloan, R. G., \& Sweeney, A. P. (1995). Detecting Earnings Management. The Accounting Review, 70(2), 193-225.

Dewi, K. C. (2013). Pengaruh Pergantian CEO (Chief Executive Officer) Terhadap Kinerja Perusahaan Dengan Manajemen Laba Sebagai Variabel Intervening (Studi Empiris pada Perusahaan Manufaktur yang Terdaftar di Bursa Efek Indonesia).Naskah Publikasi, Universitas Muhammadiyah Surakarta.

Dewi, N. M. A. K., \& Rasmini, N. K. (2018). Perbedaan Earnings Management pada Pergantian Chief Executive Officer pada Perusahaan Manufaktur yang Terdaftar di BEI. E-Jurnal Akuntansi Universitas Udayana, 23(2), 14421469.

Eisenhardt, K. M. (1989). Agency Theory: and An Assessment Review. The Academy of Management Review, 14(1), 57-74.

Erawan, I. G. P., \& Ulupui, I. G. K. A. (2013). Manajemen Laba Sebelum Dan Sesudah Pergantian Chief Executive Officer ( CEO ). E-Jurnal Akuntansi Universitas Udayana, 3(1), 55-72.

Ghozali, H. I. (2016). Aplikasi Analisis Multivariete dengan Program IBM SPSS 23. Semarang: Universitas Diponegoro.

Gill, A., Biger, N., \& Mand, H. S. (2013). Earnings Management , Firm Performance, and the Value of Indian Manufacturing Firms. Iternational Research Journal of Finance and Economics, (116), 121-131.

Hardiningsih, P., \& Oktaviani, R. M. (2012). Efektifitas Corporate Governance, Corporate Social Responsibility, dan Earning Management Terhadap Nilai Perusahaan (Perspektif Expectacy Theory dan Agency Theory). Conferene In Business, Accounting and Management (CBAM), 1(1), 803-817.

Hazarika, S., Karpoff, J. M., \& Nahata, R. (2012). Internal Corporate Governance, CEO Turnover, and Earnings Management. Journal of Financial Economics, 104(1), 44-69. 
Herawaty, V. (2008). Peran Praktek Corporate Governance Sebagai Moderating Variable dari Pengaruh Earnings Management Terhadap Nilai Perusahaan. Jurnal Akuntansi Dan Keuangan, 10, 97-108.

Jayanthi, P. Y., \& Putra, I. W. (2013). Manajemen Laba dan Respon Pasar Di Sekitar Pergantian CEO. E-Jurnal Akuntansi Universitas Udayana, 5(1), 147-162.

Jensen, C., \& Meckling, H. (1976). Theory of the Firm : Managerial Behavior, Agency Costs and Ownership Structure. Journal of Financial Economics, 3(4), 305-360.

Jiraporn, P., Miller, G. A., Yoon, S. S., \& Kim, Y. S. (2008). Is Earnings Management Opportunistic or Beneficial? An Agency Theory Perspective. International Review of Financial Analysis, 17(3), 622-634.

Kalyta, P. (2009). Accounting Discretion, Horizon Problem, and CEO Retirement Benefits. The Accounting Review, 84(5), 1553-1573.

Lesmana, I. P. A. S., \& Sukartha, I. M. (2017). Pengaruh Manajemen Laba Pada Nilai Perusahaan Manufaktur Yang Terdapat Di Bursa Efek Indonesia Tahun 2012-2015. E-Jurnal Akuntansi Universitas Udayana, 19(2), 1060-1087.

Lestari, L. S., \& Pamudji, S. (2013). Pengaruh Earnings Management Terhadap Nilai Perusahaan Dimoderasi Dengan Praktik Corporate Governance ( Studi Empiris Pada Perusahaan Non Keuangan yang Terdaftar di Bursa Efek Indonesia Tahun 2008 - 2011 ). Diponegoro Journal Of Accounting, 2(3), 19.

Mostafa, W. (2017). The Impact Of Earnings Management On The Value Relevance Of Earnings: Empirical Evidence From Egypt. Managerial Auditing Journal, 32(1), 50-74.

Pourciau, S. (1993). Earnings Management And Nonroutine Executive Changes. Journal of Accounting and Economics, 16(1-3), 317-336.

Saiful. (2004). Hubungan Manajemen Laba (Earning Management) dengan Kinerja Operasi dan Return Saham di sekitar IPO. Jurnal Riset Akuntansi Indonesia, 7(3), 316-332.

Schipper, K. (1989). Commentary on Earnings Management. Accounting Horizons, 91-102.

Scott, W. R. (2015). Financial accounting (7th ed.). Toronto: Pearson.

Siallagan, H. (2009). Pengaruh Kualitas Laba Terhadap Nilai Perusahaan. Jurnal 
Akuntansi Kontemporer, 1(1), 21-32.

Subanidja, S., Rajasa, A., Suharto, E., \& Atmanto, J. D. (2016). The Determinants Of Firm Value: The Role Of Earnings Management And Good Corporate Governance. Corporate Ownership and Control, 13(4), 609-615.

Sugiyono. (2016). Metode Penelitian Kuantitatif, Kualitatif dan $R \& D$. Bandung: C.V. Alfabeta.

Sukartha, I. M. (2007). Pengaruh Manajemen Laba, Kepemilikan Manajerial, dan Ukuran Perusahaan pada Kesejahteraan Pemegang Saham Perusahaan Target Akuisisi. Tesis, Universitas Gajah Mada Yogyakarta.

Susanto, S., \& Christiawan, Y. J. (2016). Pengaruh Earnings Management Terhadap Firm Value. Business Accounting Review, 4(1), 12.

Ung, D. 2008. (2008). Earnings Management Surrounding CEO Changes in the Neteherlands. Accounting and Finance.Thesis, Erasmus University Rotterdam.

Vancil, R. F. (1987). Passing the Baton: Managing the Process of CEO Succession. Harvard Business School Press.

Wells, P. (2002). Earnings Management Surrounding CEO Changes. Accounting and Finance, 42(169), 193.

Wijaya, B. A., \& Ardiana, P. A. (2014). Manajamen Laba Pada Peristiwa Pergantian Chief Executive Officer. E-Jurnal Akuntansi Universitas Udayana, 2, 263-278.

www.beritasatu.com. (2015). Skandal Mark Up Laba Perusahaan, CEO Toshiba Mundur. Retrieved June 8, 2018, from http://www.beritasatu.com/dunia/292689-skandal-mark-up-laba-perusahaanceo-toshiba-mundur.html

www.detikfinance.com. (2015). Saham Dibekukan 4 Bulan, Inovisi Diduga Manipulasi Laporan Keuangan. Retrieved June 8, 2018, from http://www.medanbisnisdaily.com/news/read/2015/05/18/164217/sahamdibekukan-4bulan-inovisi-diduga-manipulasi-laporan keuangan/\#.WAVVJYMrLIU

www.economy.okezone.com. (2017). Delisting Saham Inovisi Infracom, BEI Tanggung Jawab Dong ke Investor. Retrieved June 8, 2018, from https://economy.okezone.com/read/2017/10/11/278/1793478/delistingsaham-inovisi-infracom-bei-tanggung-jawab-dong-ke-investor 